\title{
Produksi, kualitas dan cita rasa tempe biji labu kuning, biji bunga matahari dan kacang adzuki
}

Production, Quality, and Taste of Tempeh Pumpkin Seeds, Sunflower Seeds and Adzuki Beans

Tati Barus $^{1)^{*}}$, Jazzieca Yokota ${ }^{1)}$, Rory Anthony Hutagalung ${ }^{1)}$

${ }^{1}$ Fakultas Teknobiologi, Universitas Katolik Indonesia Atma Jaya, Jakarta 12930, Indonesia

"Email korespondensi: tati.barus@atmajaya.ac.id

Informasi Artikel:

Dikirim: 16/02/2021; disetujui: 15/07/2021; diterbitkan: 25/09/2021

\begin{abstract}
Tempeh is a traditional Indonesian fermented food that can be processed from various types of raw materials. However, the most widely produced is soybean tempeh, so the available types of tempeh are limited. It is necessary to study the alternative raw material for tempeh apart from soybeans. Therefore, this study aims to examine the taste, antioxidants, and composition of tempeh made from pumpkin seeds, sunflower seeds, and adzuki beans. Tempeh is processed in the laboratory using soybean/ TK, pumpkin seeds/ TL, sunflower seeds/ TBM, adzuki seeds/ TA, and a mixture of all (1: 1: 1: 1) / TC. The results showed that all of the tempeh had a white surface, a compact texture that did not fall off when cut, and a distinctive aroma of tempeh without the smell of ammonia. These parameters are in line with soybean tempeh regulated in SNI 3144: 2015. The protein content and fat content of all tempeh are higher than the quality requirements of soybean tempeh which are regulated in SNI 3144: 2015. However, only the taste of TK, TBM, and TC Tempeh were well received by the panelists. The antioxidant activity of the three types of tempeh was not significantly different, but the highest was found in TBM Tempeh. Thus, pumpkin seeds, sunflower seeds, and a mixture of soybeans, pumpkin seeds, sunflower seeds, adzuki beans have the potential to be developed as raw materials for tempeh. However, further research is still needed to examine the functional properties of the TK, TBM, and TC Tempeh and their effects on the health and balance of the intestinal microbiota.
\end{abstract}

Keywords: tempeh, soybean, pumpkin seeds, adzuki beans, sunflower seeds

\begin{abstract}
ABSTRAK
Salah satu makanan fermentasi khas Indonesia adalah tempe. Tempe dapat diolah dari berbagai jenis bahan baku. Namun tempe yang banyak diproduksi dan dikonsumsi adalah tempe kedelai sehingga ragam jenis tempe yang ada terbatas. Dengan demikian perlu dikaji terus alternatif bahan baku tempe selain kedelai. Oleh sebab itu, penelitian ini bertujuan membandingkan cita rasa, antioksidan dan komposisi tempe dari bahan kedelai dengan tempe bahan baku biji bunga matahari, kacang adzuki, biji labu kuning dan campuran semua. Pembuatan tempe dilakukan di laboratorium menggunakan bahan baku: kedelai/TK, biji bunga matahari/Tempe TBM, biji adzuki /Tempe TA, biji labu kuning/Tempe TL dan campuran semua (1:1:1:1)/ Tempe TC. Hasil penelitian menunjukkan bahwa semua tempe memiliki permukaan yang warna putih, tekstur kompak sehingga saat dipotong tidak rontok, dan aromanya berbau khas tempe tanpa bau amonia. Parameter tersebut sesuai dengan syarat mutu tempe kedelai yang diatur pada SNI 3144:2015. Berdasarkan hasil uji organoleptik, semua tempe, kecuali Tempe
\end{abstract}


TA, memiliki cita rasa yang diterima dengan baik oleh panelis. Semua tempe, kecuali Tempe TA, memiliki kadar protein dan kadar lemak memenuhi syarat mutu tempe kedelai pada SNI 3144:2015. Semua tempe memiliki aktivitas antioksidan namun tidak berbeda nyata, dan yang tertinggi ditemukan pada Tempe TBM. Dengan demikian maka biji labu kuning, biji bunga matahari, dan campuran kedelai, biji labu kuning, biji bunga matahari, kacang adzuki $(1: 1: 1: 1: 1)$ berpotensi dikembangkan sebagai bahan baku tempe. Penelitian lebih lanjut masih diperlukan untuk mengkaji sifat fungsional Tempe: TK, TBM dan TC tersebut dan mengkaji pengaruhnya terhadap kesehatan dan keseimbangan mikrobiota usus.

Kata kunci: tempe, kedelai, biji labu kuning, kacang adzuki, biji bunga matahari

\section{PENDAHULUAN}

Makanan fermentasi dapat berperan menjaga keseimbangan komunitas mikrobiota usus yang baik. Publikasi yang melaporkan pentingnya peran mikrobiota usus terhadap kesehatan terus meningkat. Sejak tahun 1998 hingga 2018 telah tercatat 2,891 publikasi penelitian ilmiah terkait mikrobiota usus (Huang et al., 2019). Telah dilaporkan mikrobiota usus berpengaruh secara langsung maupun tidak langsung terhadap kesehatan mental (Clapp et al., 2017), autoimmun (Zhang, Zhao dan $\mathrm{Li}$, 2020), alergi (Berni et al., 2019) dan hipertensi (Daliri et al., 2020). Mikrobiota usus berhubungan serat dengan fungsi otak (Collins, Surette dan Bercik, 2012) sehingga ada istilah usus merupakan otak kedua manusia sehingga dapat mempengaruhi perilaku dan mood seseorang. Oleh sebab itu sangat penting untuk menjaga kesehatan dan keseimbangan mikrobiota usus yang baik. Salah satu jenis makanan yang baik dikonsumsi untuk untuk menjaga kesehatan mikrobiota usus adalah makanan fermentasi.

Tempe makanan fermentasi khas Indonesia. Mengkonsumsi tempe dapat meningkatkan meningkatkan jumlah Akkermansia muciniphila pada sistem pencernaan (Stephanie et al., 2017). Keberadaan A. muciniphila pada usus penting untuk kesehatan (Dao et al., 2016; Depommier et al., 2019). Tempe juga telah dilaporkan mengandung vitamin B12 (Keuth dan Bisping, 1994), mengandung antioksidan (Barus, Maya dan Hartanti, 2019) dan merupakan sumber protein penting yang harganya relatif murah dibandingkan sumber protein dari bahan pangan lain, seperti telur, ikan dan daging. Handajani et al., 2020 melaporkan mengkonsumsi tempe dapat meningkatkan kemampuan kognitif pada para lanjut usia.

Tempe yang diproduksi dan dikonsumsi pada umumnya adalah tempe kedelai. Namun, pembuatan tempe dapat dilakukan dari bahan baku selain kedelai, seperti biji labu kuning dan biji bunga matahari. Kedua jenis biji-bijian ini memiliki kandungan essential oil, vitamin $\mathrm{E}$ dan senyawa asam folat yang baik. Biji labu kuning telah dilaporkan memiliki kadar fenolik yang tinggi (Gumolung, 2018). Selain biji labu kuning dan biji bunga matahari, ada juga kacang adzuki yang memiliki aktivitas antioksidan yang tinggi (Amarowicz et al., 2007).

Penelitian ini bertujuan untuk mengkaji sifat sensori, aktivitas antioksidan dan komposisi kimia tempe yang diolah dari bahan baku: biji bunga matahari, kacang adzuki, biji labu kuning, dan campuran semuanya dengan perbandingan 1:1:1:1. Implikasi dari hasil penelitian ini adalah untuk mengurangi ketergantungan terhadap impor kedelai dan menambah ragam jenis tempe yang diproduksi dan dikonsumsi di Indonesia.

\section{METODE}

\section{Bahan}

Bahan yang digunakan adalah kedelai (Glycine max (L) Merrill), biji labu kuning (Cucurbita moschata), biji bunga matahari (Helianthus annuus), kacang adzuki (Vigna angularis) yang dibeli dari beberapa 
pedagang di Jakarta, inokulum tempe, etanol absolut (Smart Lab, Indonesia), dan larutan 2,2-diphenyl-1-picrylhydrazyl

(Sigma Aldrich, Jerman).

\section{Alat}

Alat yang digunakan adalah pengering beku (freeze dryer), food processor (Panasonic, Indonesia), waterbath (Memmert WB-10, Jerman), conical tube $25 \mathrm{~mL}$, sentrifugasi, dan spektrofotometer (Thermo Fisher Scientific Genesys-20, United State).

\section{Pembuatan tempe}

Proses pembuatan tempe dilakukan menggunakan bahan kedelai (Tempe K), biji labu kuning (Tempe TK), biji bunga matahari (Tempe TBM), kacang adzuki (Tempe TA) dan campuran semua dengan perbandingan 1:1:1:1) sesuai dengan metode Barus net al., (2008) dengan modifikasi. Masing-masing bahan baku dibersihkan dari pengotor lalu dicuci. Selanjutnya dilakukan perendaman I, perebusan I, perendaman II (setelah pengupasan kulit khusus pada kedelai) dan perebusan II dengan masing masing waktu seperti Tabel 1.

Tabel 1. Waktu perendaman dan perebusan bahan baku tempe

\begin{tabular}{lcccc}
\hline Jenis bahan baku tempe & \multicolumn{2}{c}{ Waktu perendaman (jam) } & \multicolumn{2}{c}{ Waktu perebusan (menit) } \\
\cline { 2 - 5 } & I & II & I & II \\
\hline Kedelai & 2 & 24 & 20 & 15 \\
Biji labu kuning & 2 & 24 & 20 & 15 \\
Biji bunga matahari & 2 & 24 & 20 & 15 \\
Kacang adzuki & 48 & 24 & 90 & 15 \\
\hline
\end{tabular}

Setelah semua bahan baku dikering anginkan maka diinokulasi dengan inokulum tempe $(2 \mathrm{~g} / \mathrm{kg}$ bahan baku) dan diinkubasi pada suhu $30{ }^{\circ} \mathrm{C}$ selama 42 jam pada kemasan plastik yang telah diberi lubang. Proses pembuatan tempe diulang sebanyak 3 kali. Selanjutnya semua tempe dievaluasi dalam hal: penerimaan panelis melalui uji organoleptik (3 kali ulangan), aktivitas antioksidan dengan DPPH (3 kali ulangan) dan analisis proksimat. Analisis proksimat dilakukan 1 kali dengan mencampur masingmasing tepung tempe yang dilakukan 3 kali menjadi satu.

\section{Analisis organoleptik tempe}

Untuk uji organoleptik masing masing tempe dilakukan secara uji hedonik mengikuti metode Lawless dan Heymann (1999). Organoleptik dilakukan oleh 30 orang panelis tidak terlatih. Kriteria penilaian meliputi warna, aroma, tekstur, dan rasa, dengan skala kesukaan: 1 (sangat tidak suka), 2 (tidak suka), 3 (netral), 4 (suka), 5 (sangat suka). Sampel tempe yang diberikan kepada panelis berukuran $1 \mathrm{~cm} \times 2 \mathrm{~cm} \times 2 \mathrm{~cm}$ yang telah dikukus selama 15 menit.

\section{Pembuatan tepung tempe}

Masing-masing sebanyak $250 \mathrm{~g}$ sampel tempe dikeringkan dengan pengering beku (freeze dryer) kemudian dihaluskan dengan food processor. Selanjutnya disaring dengan saringan berukuran $300 \mu \mathrm{m}$ dan disimpan pada suhu $4{ }^{\circ} \mathrm{C}$ sebelum digunakan untuk analisis proksimat dan analisis aktivitas antioksidan.

\section{Ekstraksi antioksidan}

Ekstraksi antioksidan pada tempe dilakukan dengan mengikuti metode Ningsih, Siswanto dan Winarsa (2018) dengan modifikasi. Sebanyak $1 \mathrm{~g}$ tepung tempe dicampur dengan $10 \mathrm{~mL}$ etanol absolut dalam conical tube $25 \mathrm{~mL}$. Suspensi dimaserasi pada waterbath (Memmert WB10, Jerman) dengan suhu $65^{\circ} \mathrm{C}$ selama 1 jam. Selanjutnya suspensi disentrifugasi dengan kecepatan $5.000 \mathrm{rpm}$ selama 15 menit hingga terpisah menjadi dua fase. Supernatan yang diperoleh akan digunakan untuk pengukuran aktivitas antioksidan dengan metode DPPH.

\section{Pengukuran aktivitas antioksidan}

Pengukuran aktivitas antioksidan mengikuti metode Ningsih, Siswanto dan Winarsa (2018). Sebanyak $1 \mathrm{~mL}$ supernatan sampel dimasukkan ke dalam tabung reaksi 
yang ditutup dengan aluminium foil. Setelah itu ekstrak tersebut ditambahkan $2 \mathrm{~mL}$ larutan DPPH 0,06 mM, kemudian dihomogenisasi. Suspensi diinkubasi selama 30 menit pada suhu $37{ }^{\circ} \mathrm{C}$ lalu dilakukan pengukuran absorbansi dengan menggunakan spektrofotometer pada panjang gelombang $517 \mathrm{~nm}$. Blanko yang digunakan yaitu etanol, sedangkan kontrol menggunakan larutan DPPH dalam etanol. Aktivitas antioksidan ditunjukkan dengan adanya perubahan warna dari ungu menjadi kuning dan dapat dihitung dengan rumus:

$$
\begin{aligned}
& \text { Aktivitas antioksidan (\%) } \\
& \qquad \begin{array}{l}
=1 \\
-\frac{\text { absorbansi sampel }}{\text { absorbansi kontrol }} \\
\times 100 \%
\end{array}
\end{aligned}
$$

\section{Analisis komposisi kimia}

Sampel tepung tempe dianalisis menggunakan standar Internasional AOAC edisi ke-19 tahun 2012 (AOAC, 2012) di PT. Saraswanti Indo Genetech. Pengukuran proksimat yang dilakukan terdiri atas kadar protein, abu, lemak total, air, dan karbohidrat.

\section{Analisis statistik}

Data uji organoleptik dianalisis dengan metode analysis of variance (ANOVA) satu arah program IBM SPSS 25.0 Signifikansi diterima pada taraf kepercayaan $\mathrm{P} \leq 0,05$.

\section{HASIL DAN PEMBAHASAN}

\section{Pembuatan tempe}

Tempe kedelai (Tempe TK), tempe biji labu kuning (Tempe TL), tempe biji bunga matahari (Tempe TBM), tempe kacang adzuki (Tempe TA), dan tempe campuran semua (1:1:1:1) (Tempe TC) telah berhasil dibuat dengan menggunakan inokulum komersial (2 $\mathrm{g} / \mathrm{kg}$ bahan baku) (Gambar 1). Miselium kapang $R$. microsporus dapat tumbuh dengan baik pada masing-masing bahan baku sehingga permukaan semua tempe tampak berwarna putih. Gambar 1 menunjukkan miselium $R$. microsporus tersebut mengikat bahan baku satu sama lain sehingga tempe bersifat kompak. Hal ini mengakibatkan saat tempe dipotong tetap utuh (tidak rontok). Aroma semua tempe tersebut memiliki bau khas tempe tidak ditemukan adanya bau amoniak.

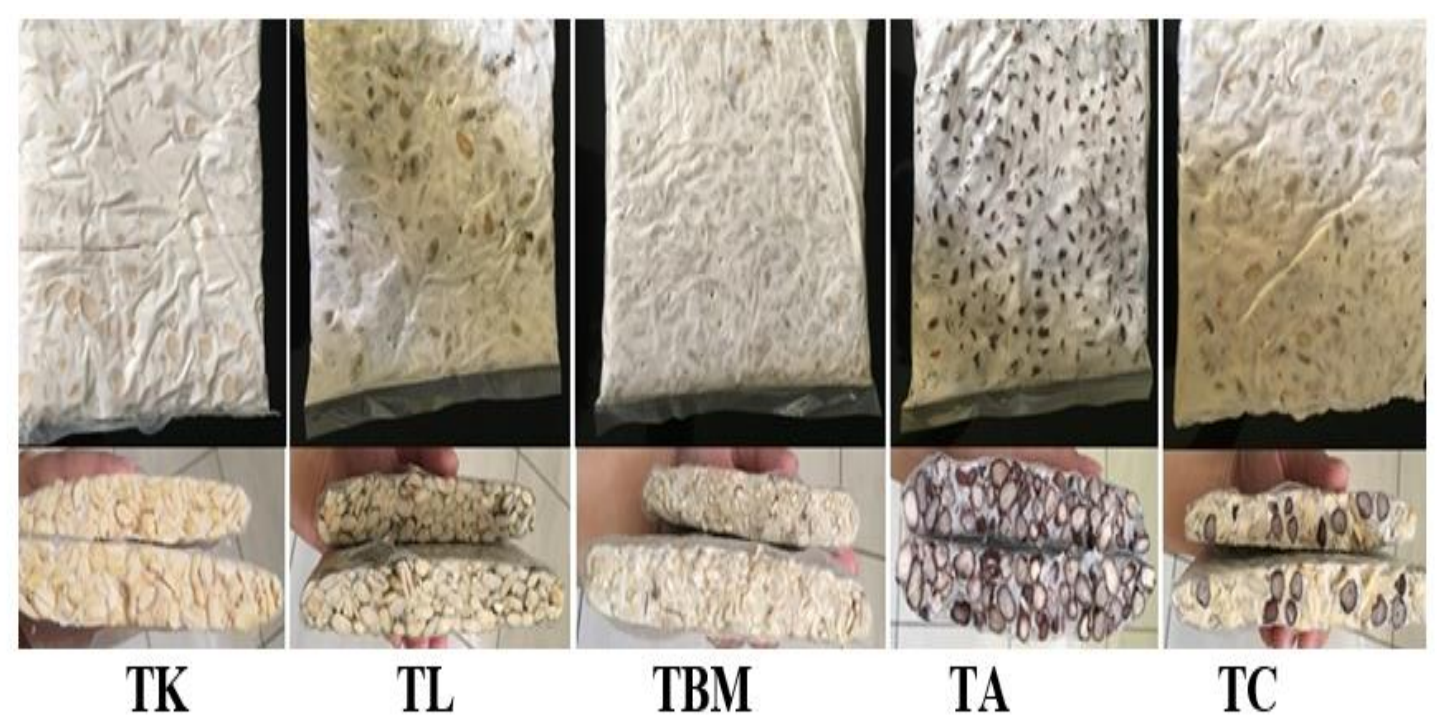

Gambar 1. Tempe berbahan baku kedelai (TK), biji labu kuning (TL), biji bunga matahari(TBM), kacang adzuki (TA), dan campuran keempatnya (1:1:1:1) (TC)

Berdasarkan warna, tekstur dan aroma (bau) semua tempe tersebut memenuhi syarat mutu tempe kedelai yang diatur pada SNI 3144:2015. Dimana menurut SNI 3144:2015 tersebut menyatakan bahwa syarat mutu tempe harus memiliki tekstur yang kompak sehingga saat diiris tetap utuh (tidak mudah rontok), berwarna putih pada seluruh permukaan tempe dan memiliki aroma bau khas tempe tanpa adanya bau amoniak. 
Namun setelah tempe dipotong tampak perbedaan ragam warna pada tempe tersebut sesuai dengan bahan baku biji bijian yang digunakan (Gambar 1). Perbedaan ragam warna pada biji-bijian tanaman akibat adanya kandungan pigmen pada masing masing bahan baku tersebut, seperti: pigmen xantofil pada kedelai (Aptesia dan Rasyid, 2013), foto klorofil pada biji labu kuning (Schoefs, 2002), fito melanin pada biji bunga matahari (Keles dan Ozdemir, 2018), dan antosianin pada kacang adzuki (Takahama, Yamauchi dan Hirota, 2013).

Saat ini, pengaturan syarat mutu hanya diperuntukkan untuk tempe kedelai, yaitu SNI 3144:2015. Hal ini karena tempe yang paling banyak diproduksi dan dikonsumsi di Indonesia adalah tempe kedelai. Namun perlu terus dikembangkan variasi jenis tempe dengan menggunakan berbagai jenis bahan baku tempe selain kedelai sehingga menambah ragam jenis tempe, seperti biji labu kuning, biji bunga matahari, kacang adzuki dan campurannya. Hal ini sudah dilakukan oleh peneliti dari berbagai negara, dimana tempe diolah dari bahan baku Phaseolus vulgaris L. (Reyes-Bastidas et al., 2010), white bean (Vital et al., 2018) dan redbean (Chen, Hsieh dan $\mathrm{Hu}, 2020$ ).

Penelitian tentang tempe dilakukan di beberapa negara karena tempe merupakan pangan fermentasi yang bersifat fungsional dan dapat diolah menjadi berbagai jenis bahan pangan turunannya. Seperti dapat membangun mikrobiota usus yang baik (Stephanie et al. 2017a), dapat meningkatkan imun sistem (Stephanie et al., 2017), mengandung antioksidan (Barus, Maya dan Hartanti, 2019; Liao, et al., 2013), dan mengandung the $\gamma$ aminobutyric acid (GABA) yang telah dilaporkan baik untuk kesehatan (Handoyo dan Morita, 2006). Tempe juga dapat diolah menjadi bahan baku pembuatan makanan dari turunannya, seperti tepung tempe untuk pembuatan beberapa jenis makanan (ReyesBastidas et al., 2010), burger tempe (Vital et al., 2018), dan sausage tempeh (Syamsuri, Dewayani dan Septianti, 2020).

Aroma tempe yang baik adalah berbau khas tempe dan tidak ada bau amonia (SNI
3144:2015). Aroma tempe muncul karena aktivitas enzimatik yang memecah berbagai macam makromolekul bahan baku tempe, seperti protease yang memecah protein serta lipase yang memecah lemak sehingga berukuran lebih sederhana dan menghasilkan senyawa yang bersifat volatil. Pada umumnya senyawa 3-octanone dan 1-octen-3-ol merupakan aroma Rhizopus spp. yang tercium (Feng, Larsen dan Schnürer, 2007). Perbedaan aroma pada masing-masing tempe disebabkan karena perbedaan komponen yang terkandung pada setiap substrat sehingga saat proses fermentasi komponen yang dipecah akan menghasilkan senyawa volatil yang berbedabeda. Mikroorganisme tersebut juga berpengaruh terhadap terbentuknya berbagai senyawa yang bersifat volatil yang berpengaruh terhadap aroma.

\section{Sifat sensori tempe}

Tabel 2 menunjukkan data hasil uji organoleptik tempe dalam hal rasa, tekstur, aroma, dan warna. Penerimaan panelis terhadap atribut rasa, tekstur dan aroma Tempe TL, Tempe TBM, dan Tempe TC cenderung tidak berbeda secara signifikan dibandingkan dengan Tempe TK. Hal ini merupakan hal yang surprise dan yang kita harapkan. Dengan demikian biji labu kuning, bunga biji matahari dan campuran antara biji labu kuning, bunga biji matahari dan kacang adzuki dapat digunakan sebagai alternatif bahan baku tempe. Dengan demikian dapat bertambah ragam jenis tempe yang dapat diproduksi yang selama ini didominasi oleh tempe kedelai. Dalam hal warna panelis paling menyukai warna Tempe TK. Hal ini kemungkinan dipengaruhi oleh warna bahan baku. Variasi warna kedelai yang kuning muda dengan miselium kapang yang berwarna putih menjadi warna yang lebih cerah sehingga menarik bagi panelis. Tabel 1 menunjukkan bahwa panelis tidak menyukai Tempe TA terhadap semua parameter yang diuji. Dengan demikian penggunaan kacang adzuki saja tidak berpotensi dikembangkan sebagai bahan baku tempe. Namun bila dicampur dengan bahan baku lain (Tempe C) menghasilkan tempe yang dapat diterima dengan baik. 
Tabel 2. Hasil organoleptik Tempe TK (kedelai), TB (biji labu kuning), TBM (biji bunga matahari), TA (kacang adzuki), TC (campuran semua dengan perbandingan 1:1:1:1)

\begin{tabular}{ccccc}
\hline Jenis tempe & Rasa & Tekstur & Aroma & Warna \\
\hline TK & $3,7 \pm 0,8^{\mathrm{b}}$ & $3,9 \pm 0,7^{\mathrm{b}}$ & $3,9 \pm 0,8^{\mathrm{c}}$ & $4,2 \pm 0,7^{\mathrm{b}}$ \\
TL & $3,4 \pm 1,1^{\mathrm{b}}$ & $3,7 \pm 0,9^{\mathrm{b}}$ & $3,6 \pm 0,8^{\mathrm{bc}}$ & $3,0 \pm 1,0^{\mathrm{a}}$ \\
TBM & $3,4 \pm 1,3^{\mathrm{b}}$ & $3,6 \pm 0,9^{\mathrm{b}}$ & $3,4 \pm 1,0^{\mathrm{b}}$ & $2,9 \pm 1,0^{\mathrm{a}}$ \\
TA & $2,5 \pm 1,1^{\mathrm{a}}$ & $2,4 \pm 1,0^{\mathrm{a}}$ & $2,9 \pm 1,0^{\mathrm{a}}$ & $3,2 \pm 1,1^{\mathrm{a}}$ \\
TC & $3,5 \pm 0,9^{\mathrm{b}}$ & $3,8 \pm 0,9^{\mathrm{b}}$ & $3,5 \pm 0,9^{\mathrm{bc}}$ & $3,0 \pm 1,2^{\mathrm{a}}$ \\
\hline
\end{tabular}

Keterangan: Hurup superscript yang berbeda pada kolom yang sama menunjukkan perbedaan yang signifikan $(\mathrm{P} \leq 0.05)$

Cita rasa tempe pada penelitian ini terutama ditentukan oleh karena jenis bahan baku yang digunakan karena semua dikondisikan sama kecuali bahan baku. Namun banyak faktor lain yang dapat mempengaruhi cita rasa tempe. Diantaranya dapat karena adanya jenis mikroorganisme yang berbeda selama proses fermentasi berlangsung. Telah dilaporkan bahwa cita rasa tempe yang disenangi panelis dan yang tidak disenangi memiliki jumlah dan jenis mikroorganisme yang sangat berbeda (Barus et al., 2008). Aktivitas mikroorganisme berbeda dapat menghasilkan peptida, asam amino bebas dan senyawa lainnya yang berbeda. Degradasi makromolekul bahan baku secara enzimatik, seperti protein oleh enzim protease berpengaruh terhadap cita rasa tempe (Zhao et al., 2018). Dimana mikroorganisme yang menghasilkan enzim, seperti Bacillus spp. yang menghasilkan enzim protease ditemukan berlimpah selama fermentasi tempe berlangsung (Barus, Wati dan Suwanto, 2017). Jenis Rhizopus berbeda dapat juga menghasilkan cita rasa berbeda (Barus, Maya dan Hartanti, 2019).

\section{Aktivitas antioksidan}

Hasil pengukuran aktivitas antioksidan melalui persen penghambatan radikal bebas dengan metode DPPH ditunjukkan pada Gambar 2. Semua tempe ditemukan memiliki aktivitas antioksidan, namun secara statistik menunjukkan perbedaan yang tidak signifikan satu dengan yang lain. Aktivitas antioksidan tertinggi ditemukan pada Tempe TBM lalu diikuti secara berurutan oleh oleh Tempe: TK, TC, TA dan TL.

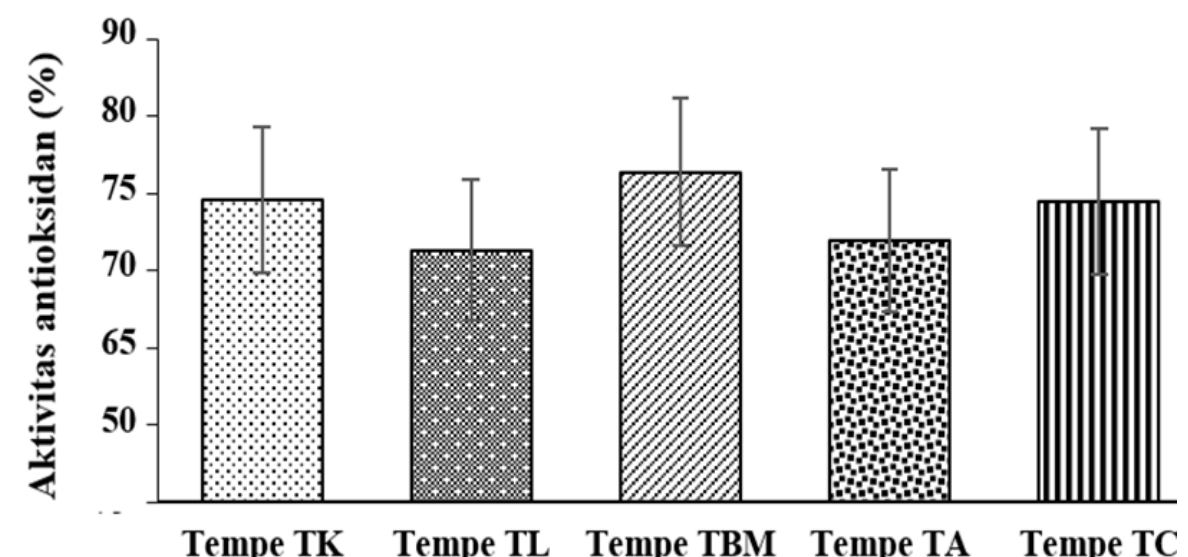

Gambar 2. Aktivitas antioksidan Tempe: TK (kedelai), TL (biji labu kuning), TBM (biji bunga matahari), TA (kacang adzuki), TC (campuran semua dengan perbandingan $1: 1: 1: 1)$

Antioksidan adalah zat atau senyawa yang sangat dibutuhkan oleh tubuh untuk menjaga kesehatan karena dapat mencegah atau memperlambat kerusakan sel akibat paparan radikal bebas. Radikal bebas dapat terbentuk di dalam tubuh sebagai produk metabolisme atau dari luar tubuh seperti polusi dan sisa pestisida pada 
makanan. Metode DPPH merupakan salah satu metode yang banyak digunakan untuk mengukur penghambatan radikal bebas dari suatu bahan makanan (Musa et al., 2013). Aktivitas antioksidan berdasarkan reduksi radikal DPPH yang berwarna violet oleh antioksidan dari makanan melalui mekanisme transfer atom hidrogen yang menyebabkan perubahan warna DPPH menjadi kuning pucat yang stabil. Lalu perubahan warna diukur dengan spektrofotometer UV-Vis pada sekitar 515 - 520 nm (Sirivibulkovit, Nouanthavong dan Sameenoi, 2018).

Keberadaan aktivitas antioksidan pada biji labu kuning ini sejalan dengan yang telah dilaporkan oleh Junita et al. (2017) dan pada tempe kedelai (Barus, Maya dan Hartanti, 2019). Namun, kadar aktivitas antioksidannya bervariasi yang kemungkinan disebabkan oleh jenis atau varietas bahan baku yang berbeda, pengolahan tempe yang berbeda, preparasi pengukuran aktivitas antioksidan yang berbeda dan jenis mikroorganisme yang berbeda selama proses fermentasi berlangsung. Perbedaan jenis mikroorganisme yang digunakan pada saat proses pembuatan tempe dapat menghasilkan aktivitas antioksidan yang berbeda (Barus, Maya dan Hartanti, 2019). Namun, sejauh ini kami belum menemukan informasi tentang aktivitas antioksidan dari tempe yang terbuat dari kacang adzuki, biji bunga matahari dan tempe yang dibuat dari campuran kacang adzuki, biji bunga matahari, biji labu kuning dan kedelai. Dengan demikian maka hasil penelitian ini yang pertama melaporkan tentang aktivitas antioksidan tempe tersebut.

\section{Komposisi kimia tempe}

Tempe merupakan sumber protein penting masyarakat Indonesia. Kadar protein tempe ditentukan oleh kadar protein bahan baku yang digunakan. Tabel
2 menunjukkan bahwa Tempe TK memiliki kadar protein tertinggi dibandingkan dengan Tempe: TL, TBM, dan TC. Hal ini karena kandungan protein kedelai yang tinggi, yaitu sekitar $45 \%$ (Liu, 1997) dan merupakan kandungan protein tertinggi diantara semua jenis kacang kacangan. Dengan demikian maka pengembangan tempe yang diperuntukkan sebagai sumber protein maka tempe berbahan baku kedelai adalah yang terbaik. Kadar protein Tempe: TK, TL, TBM, dan TC berkisar antara 21,83\% $43,51 \%$ (Tabel 1). Kadar protein semua tempe tersebut berada di atas kadar protein yang ditetapkan pada SNI 3144:2015, yaitu minimal $15 \%$.

Kadar protein Tempe LB $(34,62 \%)$ lebih rendah dibandingkan Tempe TK. Namun pemanfaatan biji labu kuning tersebut sebagai bahan baku tempe berpotensi dikembangkan sebab biji labu kuning mengandung zat besi yang tinggi (290.0 ppm) dan zinc yang tinggi (39.9 ppm). Kedua unsur tersebut penting bagi kesehatan. Kadar abu mewakili nilai kadar mineral yang terkandung pada bahan pangan. Tempe TL memiliki kadar abu yang lebih tinggi dibanding tempe lain hal ini kemungkinan karena kadar besi dan zinc pada biji labu kuning tersebut. Demikian juga kadar protein Tempe TBM $(24,68 \%)$ lebih rendah dibandingkan Tempe TK. Walaupun demikian, pemanfaatan biji bunga matahari tersebut berpotensi dikembangkan sebab mengandung E (alpha-tocopherol) yang tinggi dan kadar lemak jenuh yang tinggi (Škrbic dan Cvejanov 2011; Franco, Iseppi dan Taverna, 2018). Dengan demikian maka pengembangan tempe yang diperuntukkan sebagai sumber nutrisi lemak yang sehat maka tempe berbahan baku biji bunga matahari adalah yang terbaik. 
Tabel 3. Uji proksimat tempe TK (kedelai), TL (biji labu kuning), TBM (biji bunga matahari), TA (kacang adzuki), TC (campuran semua).

\begin{tabular}{llcccc}
\hline Kadar $(\%)$ & Tempe TK & Tempe TL & Tempe TBM & Tempe TA & Tempe TC \\
\hline Protein & 43,5 & 34,6 & 24,6 & 21,8 & 32,1 \\
Kadar abu & 2,9 & 3,9 & 3,0 & 1,6 & 2,4 \\
Lemak & 23,1 & 45,5 & 45,0 & 1,5 & 31,8 \\
Kadar air & 7,6 & 5,9 & 7,9 & 17,1 & 7,7 \\
Karbohidrat & 22,7 & 9,9 & 19,3 & 57,7 & 25,7 \\
\hline
\end{tabular}

Tabel 3 menunjukkan kadar lemak Tempe: TK, TL, TBM dan TC bervariasi mulai dari $1,59 \%$ hingga $45,52 \%$. Dengan demikian, kadar lemak Tempe: TK, TL, TBM dan TC hasil penelitian ini masih di atas kadar lemak yang ditetapkan pada SNI 3144:2015, yaitu minimal 7\%. Sebaliknya, Tempe TA memiliki kadar lemak hanya $1,59 \%$ jauh di bawah kadar lemak yang ditetapkan pada SNI 3144:2015.

Tabel 3 menunjukkan bahwa kadar lemak tertinggi ditemukan pada Tempe TBM $(45,522 \%)$. Tingginya kadar lemak tempe TBM tersebut karena kadar lemak pada biji matahari yang tinggi, yaitu sekitar $46 \%$. Minyak biji bunga matahari merupakan sumber asam lemak tidak jenuh yang paling banyak dikonsumsi di dunia. Mengandung berbagai essential oil dan vitamin E penting yang baik bagi kesehatan (Škrbic dan Cvejanov 2011; Franco, Iseppi dan Taverna, 2018). Vitamin E merupakan salah satu jenis vitamin penting untuk antioksidan yang berperan sebagai penangkal radikal bebas sehingga antioksidan Tempe TBM ditemukan paling tinggi pada penelitian ini (Gambar 2). Dengan demikian maka tempe berbahan baku biji bunga matahari adalah yang terbaik.

\section{KESIMPULAN}

Biji labu kuning, biji bunga matahari, dan campuran kedelai, biji labu kuning, biji bunga matahari, kacang adzuki (1:1:1:1:1) berpotensi dikembangkan sebagai bahan baku tempe. Namun penelitian lebih lanjut masih dibutuhkan untuk mengkaji sifat fungsional tempe yang diolah dari semua semua bahan baku tersebut dan mengkaji pengaruhnya terhadap kesehatan dan kesimbangan mikrobiota usus.

\section{UCAPAN TERIMA KASIH}

Terima kasih kepada Universitas Katolik Indonesia Atma Jaya yang telah mendanai penelitian ini melalui hibah Fakultas.

\section{DAFTAR PUSTAKA}

Amarowicz, R., Estrella, I., Hernandez, T., \& Troszyńska, A. (2008). Antioxidant activity of extract of adzuki bean and its fractions. Journal of Food Lipids, 15(1), 119-136. https://doi.org/ 10.1111/j.1745-4522.2007.00106.x

AOAC (Association of Official Analytical Chemist). 2012. Official methods of analysis, $19^{\text {th }}$ edition. Arlington

Aptesia, L. T., \& Al Rasyid, H. (2013). Pemanfaatan Lactobacillus casei dan tapioka dalam upaya menghambat kerusakan tempe kedelai. Jurnal Teknologi \& Industri Hasil Pertanian, 18(2), 175-184. http://dx. doi.org/10.23960/jtihp.v18i2.175\%20$\% 20184$

Barus, T., Maya, F., \& Hartanti, A. T. (2019). Peran beberapa galur Rhizopus microsporus yang berasal dari "laru tradisional" dalam menentukan kualitas Tempe. Jurnal Aplikasi Teknologi Pangan, 8(1), 17-22. https://doi.org/ 10.17728/jatp.3761

Barus, T., Suwanto, A., Wahyudi, A. T., \& Wijaya, H. (2008). Role of bacteria in tempe bitter taste formation: microbiological and molecular biological analysis based on 16S rRNA gene. Microbiology Indonesia, 2(1), 4-4. https://doi.org/10.5454/mi.2.1.4 
Barus, T., Titarsole, N. N., Mulyono, N., \& Prasasty, V. D. (2019). Tempeh antioxidant activity using DPPH method: effects of fermentation, processing, and microorganisms. Journal of Food Engineering and Technology, 8(2), 75-80. https:/ /doi.org/10.32732/jfet.2019.8.2.75

Barus, T., Wati, L., \& Suwanto, A. (2017). Diversity of protease-producing Bacillus spp. from fresh Indonesian tempeh based on $16 \mathrm{~S}$ rRNA gene sequence. HAYATI Journal of Biosciences, 24(1), 35-40. https://doi. org/10.1016/j.hjb.2017.05.001

Berni, C. R., Paparo, L., Nocerino, R., Di Scala, C., Della, G., Maddalena, Y., Buono, A., Bruno, C., Voto, L., \& Ercolini, D. (2019). Gut microbiome as target for innovative strategies against food allergy. Frontiers in immunology, 10, 1-40. https://doi.org/10. 3389/fimmu.2019.00191

Chen, Y. C., Hsieh, S. L., \& Hu, C. Y. (2020). Effects of red-bean tempeh with various strains of Rhizopus on GABA content and cortisol level in zebrafish. Microorganisms, 8(9), 330. https://doi.org/10.3390/microorganisms 8091330

Clapp, M., Aurora, N., Herrera, L., Bhatia, M., Wilen, E., \& Wakefield, S. (2017). Gut microbiota's effect on mental health: the gut-brain axis. Clinics and practice, 7(4), 131-136. https://doi.org/ 10.4081/cp.2017.987

Collins, S. M., Surette, M., \& Bercik, P. (2012). The interplay between the intestinal microbiota and the brain. Nature Reviews Microbiology, 10(11), 735-742. https://doi.org/10.1038/ nrmicro2876

Daliri, E. B. M., Ofosu, F. K., Chelliah, R., Lee, B. H., An, H., Elahi, F., ... \& Oh, D. H. (2020). Influence of fermented soy protein consumption on hypertension and gut microbial modulation in spontaneous hypertensive rats. Bioscience of microbiota, food and health 39(4), 199-
208. https://doi.org/10.12938/bmfh. 2020-001

Dao , M. C., Everard, A., Aron-Wisnewsky, J., Sokolovska, N., Prifti, E., Verger, E. O., ... \& MICRO-Obes Consortium. (2016). Akkermansia muciniphila and improved metabolic health during a dietary intervention in obesity: relationship with gut microbiome richness and ecology. Gut, 65(3), 426436. 10.1136/gutjnl-2014-308778

Depommier, C., Everard, A., Druart, C., Plovier, H., Van Hul, M., Vieira-Silva, S., ... \& Cani, P. D. (2019). Supplementation with Akkermansia muciniphila in overweight and obese human volunteers: a proof-of-concept exploratory study. Nature medicine, 25(7), 1096-1103. https://doi. org/10.1038/s41591-019-0495-2

Feng, X. M., Larsen, T. O., \& Schnürer, J. (2007). Production of volatile compounds by Rhizopus oligosporus during soybean and barley tempeh fermentation. International journal of food microbiology, 113(2), 133-141. https://doi.org/10.1016/j.ijfoodmicro.20 06.06.025

Franco, R., Iseppi, L., \& Taverna, M. (2018). Sunflower oil functional properties for specialty food. Nutrition and Food Science International Journal, 5(4), 4-7. http://dx.doi.org/10.19080/NFSIJ. 2018.05.555668

Gumolung D. 2018. Analisis kandungan total fenolik pada jonjot buah labu kuning (Cucurbita moschata). Fullerene Journal of Chemistry,3(1), 1-4. https://doi.org/10.37033/fjc.v3i1.25

Handajani, Y. S., Turana, Y., Yogiara, Y., Widjaja, N. T., Sani, T. P., Christianto, G. A. M., \& Suwanto, A. (2020). Tempeh consumption and cognitive improvement in mild cognitive impairment. Dementia and geriatric cognitive disorders, 49, 1-6. https://doi.org/10.1159/000510563

Handoyo, T., \& Morita, N. (2006). Structural and functional properties of fermented soybean (tempeh) by using Rhizopus 
oligosporus. International Journal of Food Properties, 9(2), 347-355. https://doi.org/10.1080/1094291050022 4746

Huang, X., Fan, X., Ying, J., \& Chen, S. (2019). Emerging trends and research foci in gastrointestinal microbiome. Journal of translational medicine, 17(1), 1-11.

Junita, D., Setiawan, B., Anwar, F., \& Muhandri, T. (2017). Komponen gizi, aktivitas antioksidan dan karakteristik sensori bubuk fungsional labu kuning (Cucurbita moschata) dan tempe. Jurnal Gizi dan Pangan, 12(2), 109-116. https://doi.org/10.25182 /jgp.2017.12.2.109-116

Keles, Y., \& Özdemir, Ö. (2018). Extraction, purification, antioxidant properties and stability conditions of phytomelanin pigment on the sunflower seeds. International Journal of Secondary Metabolite, 5(2), 140-148. https://doi.org/10.1016/j.foodchem.201 3.06.112

Keuth, S., \& Bisping, B. (1994). Vitamin B12 production by Citrobacter freundii or Klebsiella pneumoniae during tempeh fermentation and proof of enterotoxin absence by PCR. Applied and environmental microbiology, 60(5), 1495-1499.

Lawless, H. T., \& Heymann, H. (1999). Discrimination testing. In Sensory evaluation of food (pp. 116-139). Springer, Boston, MA.

Liao, W. C., Wang, C. Y., Shyu, Y. T., Yu, R. C., \& Ho, K. C. (2013). Influence of preprocessing methods and fermentation of adzuki beans on $\gamma$ aminobutyric acid (GABA) accumulation by lactic acid bacteria. Journal of Functional Foods, 5(3), 1108-1115. https://doi.org/ 10.1016/j.jff.2013.03.006

Liu, K. (1997). Chemistry and nutritional value of soybean components. In Soybeans (pp. 25-113). Springer, Boston, MA.
Musa, K. H., Abdullah, A., Kuswandi, B., \& Hidayat, M. A. (2013). A novel high throughput method based on the DPPH dry reagent array for determination of antioxidant activity. Food chemistry, 141(4), 4102-4106.

Ningsih, T. E., Siswanto, S., \& Winarsa, R. (2018). Aktivitas antioksidan kedelai edamame hasil fermentasi kultur campuran oleh Rhizopus oligosporus dan Bacillus subtilis. Berkala Sainstek, 6(1), 17-21. https://doi.org/ 10.19184/bst.v6i1.7556

Reyes-Bastidas, M., Reyes-Fernández, E. Z., López-Cervantes, J., Milán-Carrillo, J., Loarca-Piña, G. F., \& Reyes-Moreno, C. (2010). Physicochemical, nutritional and antioxidant properties of tempeh flour from common bean (Phaseolus vulgaris L.). Food Science and Technology International, 16(5), 427$434 . \quad$ https://doi.org/10.1177/ 1082013210367559

Schoefs, B. (2002). Chlorophyll and carotenoid analysis in food products. Properties of the pigments and methods of analysis. Trends in food science \& technology, 13(11), 361-371. https:// doi.org/10.1016/S0924-244(02)00182-6

Sirivibulkovit, K., Nouanthavong, S., \& Sameenoi, Y. (2018). based DPPH assay for antioxidant activity analysis. Analytical sciences, 34(7), 795-800. https://doi.org/10.2116 /analsci.18P014

Škrbić, B., \& Cvejanov, J. (2011). The enrichment of wheat cookies with higholeic sunflower seed and hull-less barley flour: Impact on nutritional composition, content of heavy elements and physical properties. Food Chemistry, 124(4), 1416-1422. https://doi.org/10.1016/j.foodchem.201 0.07.101

SNI (Standar Nasional Indonesia) 3144-2015 Tempe Kedelai. 2015. Badan Standarisasi Nasional. Jakarta.

Stephanie, S., Ratih, N. K., Soka, S., \& Suwanto, A. (2017). Effect of tempeh supplementation on the profiles of 
human intestinal immune system and gut microbiota. Microbiology Indonesia, 11(1), 2. https://doi.org/10. 5454/mi.11.1.2

Syamsuri, R., Dewayani, W., \& Septianti, E. (2020, October). Chemical characteristic and sensory of tempeh sausage on different soybean varieties and cooking methods variation. In IOP Conference Series: Earth and Environmental Science, 575(1). IOP Publishing. https://doi.org/10.1088/ 1755-1315/575/1/012012

Takahama, U., Yamauchi, R., \& Hirota, S. (2013). Isolation and characterization of a cyanidin-catechin pigment from adzuki bean (Vigna angularis). Food chemistry, 141(1), 282-288. https://doi. org/10.1016/j.foodchem.2013.02.113

Vital, R. J., Bassinello, P. Z., Cruz, Q. A., Carvalho, R. N., De Paiva, J., \& Colombo, A. O. (2018). Production, quality, and acceptance of tempeh and white bean tempeh burgers. Foods, 7(9), $136 . \quad$ https://doi. org/10.3390/foods7090136
Zhang, X., Zhao, L. D., \& Li, H. (2020). The gut microbiota: emerging evidence in autoimmune diseases. Trends in molecular medicine 16(9), 862-873. https://doi.org/10.1016/j.molmed.2020. 04.001

Zhao, G., Ding, L. L., Yao, Y., Cao, Y., Pan, Z. H., \& Kong, D. H. (2018). Extracellular proteome analysis and flavor formation during soy sauce fermentation. Frontiers in microbiology, 9, 1-7. https://doi.org/ 10.3389/fmicb.2018.01872 